\title{
ANALYSIS INTO THE SELECTION OF A BALLAST WATER TREATMENT SYSTEM
}

\author{
Diana Šateikienè $\dot{1}^{1}$ Jolanta Janutėniené ${ }^{2}$, Marijonas Bogdevičius ${ }^{3}$, Rima Mickevičiené ${ }^{4}$ \\ ${ }^{1,4}$ Dept of Ship Engineering, Klaipeda University, Lithuania \\ ${ }^{2}$ Dept of Mechanical Engineering, Klaipeda University, Lithuania \\ ${ }^{3}$ Dept of Transport Technological Equipment, Vilnius Gediminas Technical University, Lithuania
}

Submitted 27 October 2013; resubmitted 16 February 2014, 19 May 2014; accepted 31 July 2014

\begin{abstract}
Today, it is very important to select and install the optimal equipment for the treatment of ballast water in existing ships. Increasing cargo volumes demand for a greater number of ships for transportation and expanded navigation geography as well as result in increased amount of discharged ballast water. Consequently, sea water pollution is increasing and invasive microorganisms appear that the existing flora and fauna are unaccustomed to. In order to protect territorial waters from these invasive species, International Maritime Organization (IMO) requirements have been implemented that regulate the quality parameters of discharged ballast water from ships. This problem has become particularly relevant for operational ships, in which ballast water treatment equipment and technical solutions had not been anticipated in the design stage. This article provides a comparative analysis of the treatment equipment of ballast water and the related technical parameters, in order to distinguish the most important equipment criteria. A Carrier, according to its technical characteristics, was analysed together with the water treatment method for operated bulk. An expert evaluation for the characteristics of the technical equipment was established.
\end{abstract}

Keywords: ship; seawater; ballast water treatment; treatment methods; multi-criteria evaluation.

\section{Introduction}

Ballast water is used to stabilise vessels by taking ballast water into tanks from one global ocean harbour while the ship is unloading and to discharge it in another place while the ship is loading. This leads to the introduction of invasive species. In 2004, the International Maritime Organization (IMO) adopted the International Convention for the Control and Management of Ships' Ballast Water and Sediments (BWM) (IMO 2004). The Convention will enter into force once it has been ratified by 30 States, representing $35 \%$ of the world merchant shipping tonnage. Ships built after 2009 with a ballast tank capacity below $5000 \mathrm{~m}^{3}$ and ships newly built on and after 1 January 2012 with a ballast tank capacity of $5000 \mathrm{~m}^{3}$ and over will have to have ballast water treatment systems installed by the time the convention is enacted. Systems for a ballast water management shell are approved by the authorities of the Flag State of the ship. Today, there are many known ballast water treatment methods and equipment suppliers and, therefore, for ship owners and operators it is often rather difficult to select the most suitable ballast water treatment system for their ship in terms of efficiency, price and duration of installation works, operational expenditures, etc. In operating ships, the engine room mostly has a narrow available pathway to move the ballast water treatment system's components and, normally, there is no space around the pumps.

The other trouble such as peaking retrofit demand and the lack of sufficient industrial capacity could happen if ship owners of possible 49300 ships, which need to be outfitted, postpone the ballast water treatment system installation to an intermediate survey, with this being the latest point for a ship to comply with global regulations in a few years' time.

The Ballast Water Management Convention (IMO 2004) has not yet entered into force, but the schedule for mandatory treatment of ballast water is fixed independent of when the convention is ratified. The main peak is expected in 2017, when the last ships with medium ballast water capacity have to retrofit at the same time as the rest of the fleet has to start retrofitting. After 2019, the retrofitting is expected to be largely completed. It is good

Corresponding author: Diana Šateikienè

E-mail:diana.s@balticum-tv.lt 
news for ship equipment manufacturers and shipyards. They need to be prepared to deliver their products and provide services to shipping companies.

Nowadays, one of the most serious problems is the aquatic invasive species: spread of organisms from ship ballast water that is emergent in maritime surroundings (Wu et al. 2011a, 2011b; Drake, Lodge 2004; Gregg et al. 2009; Endresen et al. 2004). In order to prevent these organisms from spreading, ballast water treatment systems should be installed in all ships (Gollasch et al. 2007; David, Gollasch 2008).

Globally, research has been carried out on the analysis of mechanical, physical, and chemical methods and their combinations: filtration and hydrocyclonic separation (Tang et al. 2006, 2009), deoxygenation (David, Gollasch 2008; McCollin et al. 2007), ozonation (Oemcke, Van Leeuwen 2005; Perrins et al. 2006), chemical biocides (Zhang et al. 2013), UV (Wu et al. 2011a, 2011b; Holm et al. 2008; Raikow et al. 2007), ultrasound or a combination of these methods, e.g. filtration or hydrocyclone as a primary treatment and ultraviolet light as a secondary one (Champ 2002; Tang et al. 2006; Sutherland et al. 2001).

Each method has its own advantages and disadvantages. According to factors of safety, effectiveness and cost, a single method does not ensure fulfilment of requirements posed by the IMO (Wu et al. 2011a, 2011b).
The aim of this article is to show how to select the possible most popular ballast water treatment system for bulk carries' retrofitting with the help of a survey issued to maritime industry experts and the analysis of their point of view.

\section{Research Selection Criteria of the Ballast Water Cleaning Equipment}

\subsection{The Overview of Ballast Water Treatment Methods}

At the moment, modern ballast water treatment equipment is based on mechanical (filtration and hydrocyclonic separation), physical (UV radiation and deoxidation) and chemical (ozonation, chlorination and electrolysis) treatment methods (Table 1).

Each treatment technology has different characteristics and features and differs from others by several aspects.

Understanding the differences and limitations between the treatment technologies used by the ballast water treatment systems available on the market could be the first step in starting to select a ballast water treatment system for a ship, even if almost all the systems on the market make use of more than one technology to overcome possible technology limitations and to reach full compliance with the D-2 Standard (IMO 2004).

Table 1. Ship’s ballast water treatment methods (Tang et al. 2006; Sutherland et al. 2001; Šateikiené, Janutèniené 2012)

\begin{tabular}{|c|c|c|c|}
\hline $\begin{array}{l}\text { Ballast water } \\
\text { treatment } \\
\text { methods }\end{array}$ & Ship and operations & Safety & Environments \\
\hline Filtration & $\begin{array}{l}\text { Treatment at: uptake; } \\
\text { Time for lethality: at treatment; } \\
\text { Pressure drops and reduced flow rate. }\end{array}$ & No safety related effects. & $\begin{array}{l}\text { Reduction of sediments into the ballast } \\
\text { tanks; } \\
\text { Not effective for microorganisms. }\end{array}$ \\
\hline $\begin{array}{l}\text { Cyclonic } \\
\text { separation }\end{array}$ & $\begin{array}{l}\text { Treatment at: uptake; } \\
\text { Time for lethality: at treatment; } \\
\text { Pressure drops and reduced flow rate; } \\
\text { Minimum maintenance. }\end{array}$ & No safety related effects. & $\begin{array}{l}\text { Reduction of sediments into the ballast } \\
\text { tanks; } \\
\text { Not effective for microorganisms. }\end{array}$ \\
\hline $\begin{array}{l}\text { Coagulation/ } \\
\text { flocculation }\end{array}$ & $\begin{array}{l}\text { Treatment at: uptake; } \\
\text { Time for lethality: n/a; } \\
\text { Storage tanks for additives are } \\
\text { necessary. }\end{array}$ & N/a. & $\begin{array}{l}\text { Reduction of sediments into the ballast } \\
\text { tanks; } \\
\text { Not effective for microorganisms. }\end{array}$ \\
\hline UV & $\begin{array}{l}\text { Treatment at: uptake and discharge; } \\
\text { Time for lethality: at treatment; } \\
\text { Increased energy consumption; } \\
\text { High maintenance. }\end{array}$ & $\begin{array}{l}\text { UV light exposure can be } \\
\text { harmful. }\end{array}$ & $\begin{array}{l}\text { Efficiency is dependent on water quality; } \\
\text { Effective for microorganisms. }\end{array}$ \\
\hline Ozonation & $\begin{array}{l}\text { Treatment at: uptake for some } \\
\text { systems and at discharge for others; } \\
\text { Time for lethality: up to } 15 \text { hours; } \\
\text { Possible consequences on tanks and } \\
\text { pipe corrosion. }\end{array}$ & $\begin{array}{l}\text { Toxic (it is a primary } \\
\text { irritant, affecting especially } \\
\text { eyes and respiratory } \\
\text { systems). }\end{array}$ & $\begin{array}{l}\text { Effective for microorganisms; } \\
\text { Ballast water neutralisation before } \\
\text { discharge; } \\
\text { Efficiency is dependent on water quality; } \\
\text { Air pollution. }\end{array}$ \\
\hline $\begin{array}{l}\text { Electrolytic } \\
\text { chlorination/ } \\
\text { electrolysis }\end{array}$ & $\begin{array}{l}\text { Treatment at: uptake; } \\
\text { Time for lethality: hours; } \\
\text { Possible consequences on tanks and } \\
\text { pipe corrosion; } \\
\text { Increased energy consumption; } \\
\text { High maintenance. }\end{array}$ & $\begin{array}{l}\text { Risk of chemical exposure } \\
\text { to the ship's crew; } \\
\text { Exhaust of hydrogen and } \\
\text { chlorination gas generated } \\
\text { by electrolysis. }\end{array}$ & $\begin{array}{l}\text { Effective for a broad range of organisms; } \\
\text { Ballast water neutralisation before } \\
\text { discharge; } \\
\text { Efficiency is dependent on water quality. }\end{array}$ \\
\hline
\end{tabular}


The technologies used for treating ballast water are generally derived from municipal and other industrial applications. Some of them are very well-known treatment applications but they are now subject to new constraints such as space on board, costs and efficacy.

\subsection{Equipment Selection Criteria}

This research includes analysed methods for the treatment of ballast water and the information about the equipment for the treatment of ballast water certified by manufacturers. The main technical characteristics of the equipment were highlighted. The maximum technical parameters of the certified equipment were collected regardless of the manufacturer of the equipment and provided in Table 2 in accordance with the method for the treatment of ballast water. The maximum values pertaining to technical characteristics of the analysed methods for the treatment of ballast water were very different.

Subsequent to the analysis of the approved treatment equipment offered by manufacturers, it is possible to distinguish the main technical parameters that have an influence on selecting dry bulk cargo ships.

Treatment equipment capacity - the maximum ballast water treatment amount per time unit: for the research, a Bulk Carriers vessel was selected (type - handy, representative ballast capacity $-18000 \mathrm{~m}^{3}$, representative pumps rate $1300 \mathrm{~m}^{3} / \mathrm{h}$ ); therefore, this parameter is important.

Treatment equipment dimensions - dimensions of treatment equipment assembled in operational ships. There are no anticipated places for treatment equipment installation in operational ships and the dimensions are limited by passages and installed equipment while transporting it to a selected place.

Treatment equipment mass - the total mass of installed equipment module. During the installation of ballast water treatment equipment in an operational ship, some additional mass appears that had not been anticipated in the design and construction stage.

Energy consumption - any newly installed treatment equipment uses energy. The equipment's energy consumption is relevant because the ship's design and construction has not foreseen additional energy consumption. Electrical power consumption by the ballast water treatment systems is potentially a significant hurdle for some technologies on the high ballast dependent ships.

\section{Multi-Criteria Evaluation Methods}

Multi-criteria decision making methods are applied for deterministic problem solving, when the set of alternatives are known and are directly determined at the beginning of the selection process: ELECTRE group of methods (ELECTRE I, ELECTRE II, ELECTRE III, ELECTRE IV, ELECTRE A, ELECTRE TRI) (Zavadskas et al. 2013; Radziszewska-Zielina 2010) are based on overbalance of the ratio and assigned to overbalance ratio approach methods and should be assigned to grouping and classification group methods according to their purpose; the PROMETHEE group of methods (PROMETHEE I, II, III and IV) (Kabak, Dağdeviren 2014; Podvezko, Podviezko 2010); and the PCCA procedure, which is the basis, on which these methods are developed: Mappac, Pragma, Cartesian methods (Matarazzo 1990; He et al. 2009); AHP method (Esmaeili et al. 2014; Rostamzadeh et al. 2014; Gudienè et al. 2014; Šiožinytė et al. 2014; Kildienè et al. 2014).

For contractor problem solving, it is necessary to distribute potential priorities. These priorities are considered from the best to the worst. For every analysis there can be applied several multi-criteria methods. The best-known methods are Goal Programming, Analytical Hierarchy Process, the ELECTRE and the PROMETHEE group of methods (Zavadskas et al. 2013; Radziszewska-Zielina 2010; Kabak, Dağdeviren 2014; Podvezko, Podviezko 2010; Esmaeili et al. 2014; Rostamzadeh et al. 2014; Gudienè et al. 2014; Šiožinytè et al. 2014; Kildienè et al. 2014).

The PROMETHEE method is assigned to ranking methods. PROMETHEE methods need a lot of information, but the number of criteria is reduced considerably. A decision maker defines the priorities of the function of each criterion and provides the following functions thresholds.

Quantitative multi-criteria methods are based the decision-making matrix $R=\left\|r_{i j}\right\|$ of criteria (indicators) that characterise the analysed process and indicator importance (weight) vectors $\Omega=\left\|\varpi_{i}\right\|$ $(i=1,2, \ldots, m ; j=1,2, \ldots, n)$, where: $m$ - the number of indicators; $n$ - the number of compared objects (alternative) $\left(\sum_{i-1}^{m} \omega_{i}=1\right)$ (Podvezko 2012).

Indicators are of a maximised or minimised type, i.e. with consideration to the analysed purpose, their

Table 2. Ballast water treatment methods and equipment and their maximum values of indicators

\begin{tabular}{llccccccc}
\hline & & & \multicolumn{5}{c}{ Methods of treatment } \\
\cline { 3 - 10 } No. $\begin{array}{c}\text { Parameters of } \\
\text { cleaning equipment }\end{array}$ & $\begin{array}{c}\text { Measurement } \\
\text { units }\end{array}$ & $\begin{array}{c}\text { Chlorine } \\
\text { generation }\end{array}$ & $\begin{array}{c}\text { Filtration }- \\
\mathrm{UV}\end{array}$ & $\begin{array}{c}\text { Elec- } \\
\text { trolysis }\end{array}$ & $\begin{array}{c}\text { Filtration }- \\
\text { UV - } \\
\text { ozonation }\end{array}$ & $\begin{array}{c}\text { Filtration - } \\
\text { electrolysis/ } \\
\text { electrochlori- } \\
\text { nation }\end{array}$ & $\begin{array}{c}\text { Coagulant } \\
\text { (with magnetic } \\
\text { particles) }\end{array}$ \\
\hline 1. & Capacity & $\mathrm{m}^{3} / \mathrm{h}$ & 9600 & 6000 & 5000 & 3000 & 6000 & 2400 \\
\hline 2. & Dimensions & $\mathrm{m}^{3}$ & 23 & 15.9 & 5.23 & 13.5 & 43.3 & 209.2 \\
\hline 3. & Equipment mass & $\mathrm{kg}$ & 7520 & 4750 & 13600 & 11000 & 7750 & 14090 \\
\hline 4. & Energy consumption & $\mathrm{kW}$ & 23.3 & 76 & 800 & 348 & 177.8 & 170 \\
\hline
\end{tabular}


best value may be the highest or the lowest. The influence of individual indicators (criteria) is different in terms of the present purpose and measurement units of criteria. Quantitative multi-criteria methods combined normalised values of criteria $\tilde{r}_{i j}\left(0 \leq \tilde{r}_{i j} \leq 1\right)$ and their weights $\omega_{i}$ with the method of evaluation criteria (Podvezko 2012; Ginevičius, Podvezko 2005; Ginevičius, Vaitkūnaitė 2006).

Depending on the SAW (Simple Additive Weighting) method, the evaluation criterion $S_{j}$ is calculated by the following formula:

$$
S_{j}=\sum_{i=1}^{m} \omega_{i} \cdot r_{i j}
$$

where: $\omega_{i}$ - weight coefficient; $r_{i j}$ - significance coefficients.

The method of alternative evaluation is the PROMETHEE (Preference Ranking Organisation METHod for Enrichment Evaluation) method. Instead of the criteria of normalised values $\tilde{r}_{i j}$ in the formula (1) priority function $p(d)$ values are applied, where $\mathrm{d}$ is the function argument and is the index (criterion) values difference $d_{i}\left(A_{j}, A_{k}\right)=r_{i j}-r_{i k}$.

Weighting coefficient value selection method is applicable, as a decision-maker selects values of the weighting coefficients, depending on the calculated task specifics, and considering the fact that the most important parameter is the quality of the clean-up, which if it not met means the other parameters of the analysis do not make sense.

The prioritisation function values indicate the degree of importance of one alternative (prioritisation) in respect of other alternatives and depend on the function parameters $q$ and $s$ (Podvezko 2012).

Evaluation with the PROMETHEE method of two alternatives $A_{j}$ and $A_{k}$ comparison criteria $\pi\left(A_{j} ; A_{k}\right)$ are calculated by the following formula:

$$
\pi\left(A_{j} ; A_{k}\right)=\left(\sum_{i=1}^{m} \omega_{i} \cdot p_{t}\left(d_{i}\left(A_{j} ; A_{k}\right)\right)\right),
$$

where: $\omega_{i}-i$-th index $R_{i}$ weight; $p_{t}(d)=p_{t}\left(d_{i}\left(A_{j}, A_{k}\right)\right)$ $t$-th (one of the proposed) priority function, for the chosen $i$-th indicator.

These methods differ from other multi-criteria methods as instead of the normalised values of criteria, specifically chosen functional (priorities, consensus and disagreement) values apply.

\section{Ballast Water Treatment Methods and the Comparative Analysis of the Equipment Index}

The importance of technical parameters of ballast water treatment equipment was analysed in order to determine the ones that need to be estimated while installing treatment systems in ships.

For expert evaluation, specialists of this field were selected: ship owners, ship designers, constructors and scientists.

An accomplished expert evaluation and to have all expert results of the evaluation is expedient in working them out. The processing of results is expedient in working out these tasks:

- set of expert opinions' compatibility;

- set of dependence between the expert opinions;

- summarise the evaluation of the experts;

- assess the reliability of the results of the expert evaluation (Rimkuviene 2002) (Table 3).

In processing the results of the expert evaluation, especially in the case in which the opinions are incompatible, it is appropriate to determine the dependency between the different expert opinions. In order to establish the unity of expert opinions as well as calculate the Kendall concordance coefficient $W$ (Čekanavičius, Murauskas 2004):

$$
W=\frac{12 \cdot S^{2}}{m^{2} \cdot\left(k^{3}-k\right)},
$$

where: $S$ - sum of squares pertaining to deviation of results received from evaluation of each criterion; $m$ - the number of experts $(m=7) ; k$ - the number of evaluation criteria $(k=4)$.

The concordance coefficient may fluctuate in the range from 0 to 1 . When $W=1$, all experts accepted all of the criteria; and when $W=0$, experts did not have a unanimous opinion. The evaluation can be considered to be sufficiently objective if $W>0.6$.

Deviation from the average of the squares of the ranks is equal to:

$$
S^{2}=\sum_{j=1}^{k}\left(\sum_{i=1}^{m} x_{i j}-a\right)^{2}=185,
$$

where: $x_{i j}-j$-th object rank of row $i ; a$ - the average value of ranks:

$$
a=0.5 \cdot m \cdot(k+1)=17.5 \text {. }
$$

When the concordance coefficient exceeds the value of 0.6 , it is assumed that the expert opinion is unanimous and the expert assessment is deemed to be reliable and completed (Birks, Malhotra 2002).

To calculate the concordance coefficient:

$$
W=\frac{12 \cdot S^{2}}{m^{2} \cdot\left(k^{3}-k\right)}=\frac{12 \cdot 185}{7^{2} \cdot\left(4^{3}-4\right)}=0.76 .
$$

In order to test the hypothesis of the significance of $W$ it is necessary to calculate $\chi_{f}^{2}$ :

$$
\chi^{2}=\frac{12 \cdot S}{m \cdot k \cdot(k+1)}=\frac{12 \cdot 1394}{7 \cdot 4 \cdot(4+1)}=119.49,
$$

where: $\chi^{2}-$ testing criteria for the significance of concordance coefficient.

If using the following formula the calculated value is greater than the critical value, the rankings hypothesis concerted by the experts is confirmed. When $\chi^{2}<\chi_{\text {krit }}^{2}$, it is considered that expert opinions are incompatible and radically different:

$$
\chi_{k r i t}^{2}=\chi_{\alpha}^{2} \cdot(k-1)=\chi_{0.05}^{2} \cdot(3)=0.352 .
$$


Table 3. Ballast water treatment criteria

\begin{tabular}{|c|c|c|c|c|c|c|c|c|c|c|c|}
\hline \multirow{2}{*}{$\begin{array}{c}\text { The evaluation } \\
\text { criteria }\end{array}$} & \multicolumn{11}{|c|}{ Evaluation of priority } \\
\hline & 1 & 2 & 3 & 4 & 5 & 6 & 7 & $\begin{array}{l}\text { Amount } \\
\text { of ranks }\end{array}$ & Ranking & $\begin{array}{l}\text { The average } \\
\text { value of ranks }\end{array}$ & $\begin{array}{c}\text { Square } \\
\text { deviation }\end{array}$ \\
\hline Capacity & 4 & 3 & 4 & 4 & 4 & 3 & 4 & 26 & 4 & 17.5 & 72.25 \\
\hline Dimensions & 3 & 4 & 3 & 2 & 3 & 2 & 2 & 19 & 3 & 17.5 & 2.25 \\
\hline Equipment mass & 1 & 1 & 1 & 1 & 1 & 1 & 1 & 7 & 1 & 17.5 & 110.25 \\
\hline Energy consumption & 2 & 2 & 2 & 3 & 2 & 4 & 3 & 18 & 2 & 17.5 & 2.25 \\
\hline
\end{tabular}

An accomplished expert assessment and materiality of reliable analysis can accentuate the most significant and the most important factors of the selection of the ballast water treatment equipment.

The ballast water treatment methods and equipment evaluation criteria for weight coefficients are presented in Table 4.

Table 4 . The ballast water treatment methods and criteria evaluation of equipment

\begin{tabular}{lc}
\hline \multicolumn{1}{c}{ The evaluation criteria } & Weight coefficient $\omega_{i}$ \\
\hline Capacity & 0.37 \\
\hline Dimensions & 0.27 \\
\hline Equipment mass & 0.10 \\
\hline Energy consumption & 0.26 \\
\hline
\end{tabular}

Of each criteria under consideration, the ballast water treatment method and the relative importance of equipment parameters are calculated to consider the minimised or maximised normalised criteria values.

Calculated values are multiplied by the appropriate weight factor. In this case, we are interested in low bacterial spread, the minimum energy costs and the minimum overall dimensions and weight of the equipment.

Calculated by formula (1), it is estimated that these days, to produce the ballast water treatment, the minimum performance parameters $S_{\min }=2.793$ ensure the water chlorination method (Table 5).

\section{Conclusions}

Having analysed the main technical characteristics of currently manufactured equipment for the treatment of ballast water, the main technical parameters were highlighted, which would be important when choosing the equipment and installing it in ships. The rating of main technical parameters of the equipment for the treatment of ballast water using PROMETHEE method was performed and experts were surveyed. During the expertise, the main technical parameters which have to be evaluated were determined as follows: efficiency, capacity, mass and power consumption of the equipment.

Calculations regarding the coefficient of concordance revealed the compatibility of the expert opinions. The value of the coefficient of concordance is 0.76 . This result shows that experts think similarly and the expertise is considered reliable.

The results acquired from the comparative analysis of technical characteristics of the equipment for the treatment of ballast water using multi-criteria method showed that the equipment for water treatment based on chlorination is the most effective and energy efficient only in accordance with technical parameters. The treatment efficiency using chlorination method depends on chlorine concentration, ambient temperature, and salt content in water, $\mathrm{pH}$ and time of impact.

In order to achieve good results of water treatment, it is suggested to combine two measures: chlorine and filtration. It is essential to neutralise and remove all remaining chemicals from ballast water before draining it.

Table 5. The ballast water treatment methods and the assessment of equipment

\begin{tabular}{llcccccccc}
\hline & & \multicolumn{6}{c}{ Cleaning methods and equipment significance coefficients $r_{i}$} \\
\cline { 3 - 9 } No. $\begin{array}{c}\text { Parameters of } \\
\text { cleaning equipment }\end{array}$ & $\begin{array}{c}\text { Optimisation } \\
\text { direction }\end{array}$ & $\begin{array}{c}\text { Chlorine } \\
\text { generation }\end{array}$ & $\begin{array}{c}\text { Filtration }- \\
\text { UV }\end{array}$ & $\begin{array}{c}\text { Elec- } \\
\text { trolysis }\end{array}$ & $\begin{array}{c}\text { Filtration }- \\
\text { UV- ozo- } \\
\text { nation }\end{array}$ & $\begin{array}{c}\text { filtration - } \\
\text { electrolysis/ } \\
\text { electrochlorination }\end{array}$ & $\begin{array}{c}\text { Coagulant } \\
\text { (with magnetic } \\
\text { particles) }\end{array}$ \\
\hline 1. & Capacity & $\max ^{*}$ & 0.370 & 0.231 & 0.193 & 0.116 & 0.231 & 0.093 \\
\hline 2. & Dimensions & $\min$ & 0.030 & 0.021 & 0.007 & 0.017 & 0.056 & 0.270 \\
\hline 3. & Equipment mass & $\min$ & 0.053 & 0.034 & 0.097 & 0.078 & 0.055 & 0.100 \\
\hline 4. & Energy consumption & $\min$ & 0.008 & 0.025 & 0.260 & 0.113 & 0.058 & 0.055 \\
\hline & & $S_{\min }$ & 2.793 & 4.403 & 5.552 & 8.857 & 4.493 & 11.236 \\
\hline
\end{tabular}

Note: ${ }^{\star}$ measured ratios. 


\section{References}

Birks, D. F.; Malhotra, N. K. 2002. Marketing Research: an Applied Approach. 2nd edition. Financial Times/Prentice Hall. $816 \mathrm{p}$.

Champ, M. A. 2002. Marine testing board for certification of ballast water treatment technologies, Marine Pollution Bulletin 44(12): 1327-1335.

http://dx.doi.org/10.1016/S0025-326X(02)00316-8

Čekanavičius, V.; Murauskas, G. 2004. Statistika ir jos taikymai II. Vilnius: TEV, 2002. 272p. (in Lithuanian).

David, M.; Gollasch, S. 2008. EU shipping in the dawn of managing the ballast water issue, Marine Pollution Bulletin 56(12): 1966-1972.

http://dx.doi.org/10.1016/j.marpolbul.2008.09.027

Drake, J. M.; Lodge, D. M. 2004. Global hot spots of biological invasions: evaluating options for ballast-water management, Proceedings of the Royal Society B: Biological Sciences 271: 575-580. http://dx.doi.org/10.1098/rspb.2003.2629

Endresen, Ø.; Behrens, H. L.; Brynestad, S.; Andersen, A. B.; Skjong, R. 2004. Challenges in global ballast water management, Marine Pollution Bulletin 48(7-8): 615-623. http://dx.doi.org/10.1016/j.marpolbul.2004.01.016

Esmaeili, A.; Kahnali, R. A.; Rostamzadeh, R.; Zavadskas, E. K.; Sepahvand, A. 2014. The formulation of organizational strategies through integration of freeman model, swot, and fuzzy MCDM methods: a case study of oil industry, Transformations in Business \& Economics 13(3C(33C)): 602-627.

Ginevičius, R.; Podvezko, V. 2005. Daugiakriterinio vertinimo rodiklių sistemos formavimas, Verslas: teorija ir praktika 6(4): 199-207. (in Lithuanian).

Ginevičius, R.; Vaitkūnaite, V. 2006. Analysis of organizational culture dimensions impacting performance, Journal of Business Economics and Management 7(4): 201-211.

Gregg, M.; Rigby, G.; Hallegraeff, G. M. 2009. Review of two decades of progress in the development of management options for reducing or eradicating phytoplankton, zooplankton and bacteria in ship's ballast water, Aquatic Invasions 4(3): 521-565. http://dx.doi.org/10.3391/ai.2009.4.3.14

Gollasch, S.; David, M.; Voigt, M.; Dragsund, E.; Hewitt, C.; Fukuyo, Y. 2007. Critical review of the IMO international convention on the management of ships' ballast water and sediments, Harmful Algae 6(4): 585-600. http://dx.doi.org/10.1016/j.hal.2006.12.009

Gudienè, N.; Banaitis, A.; Podvezko, V.; Banaitienè, N. 2014. Identification and evaluation of the critical success factors for construction projects in Lithuania: AHP approach, Journal of Civil Engineering and Management 20(3): 350359. http://dx.doi.org/10.3846/13923730.2014.914082

He, G.; Fang, H.; Chen, M. 2009. Multidimensional upwind scheme of diagonal Cartesian method for an advectiondiffusion problem, Computers \& Fluids 38(5): 1003-1010. http://dx.doi.org/10.1016/j.compfluid.2008.01.013

Holm, E. R.; Stamper, D. M.; Brizzolara, R. A.; Barnes, L.; Deamer, N.; Burkholder, J. A. M. 2008. Sonication of bacteria, phytoplankton and zooplankton: application to treatment of ballast water, Marine Pollution Bulletin 56(6): 1201-1208. http://dx.doi.org/10.1016/j.marpolbul.2008.02.007

IMO. 2004. International Convention for the Control and Management of Ships' Ballast Water and Sediments (BWM). International Maritime Organization (IMO).

Kabak, M.; Dağdeviren, M. 2014. A hybrid MCDM approach to assess the sustainability of students' preferences for uni- versity selection, Technological and Economic Development of Economy 20(3): 391-418.

http://dx.doi.org/10.3846/20294913.2014.883340

Kildienè, S.; Zavadskas, E. K.; Tamošaitienė, J. 2014. Complex assessment model for advanced technology deployment, Journal of Civil Engineering and Management 20(2): 280290. http://dx.doi.org/10.3846/13923730.2014.904813

Matarazzo, B. 1990. A pairwise criterion comparison approach: the Mappac and Pragma methods, in C. A. Bana e Costa (Ed.). Readings in Multiple Criteria Decision Aid, 253-273. http://dx.doi.org/10.1007/978-3-642-75935-2_11

McCollin, T.; Quilez-Badia, G.; Josefsen, K. D.; Gill, M. E.; Mesbahi, E.; Frid, C. L. J. 2007. Ship board testing of a deoxygenation ballast water treatment, Marine Pollution Bulletin 54(8): 1170-1178.

http://dx.doi.org/10.1016/j.marpolbul.2007.04.013

Oemcke, D. J.; Van Leeuwen, J. H. 2005. Ozonation of the marine dinoflagellate alga Amphidinium sp.-implications for ballast water disinfection, Water Research 39(20): 51195125. http://dx.doi.org/10.1016/j.watres.2005.09.024

Perrins, J. C.; Cooper, W. J.; Van Leeuwen, J. H.; Herwig, R. P. 2006. Ozonation of seawater from different locations: formation and decay of total residual oxidant - implications for ballast water treatment, Marine Pollution Bulletin 52(9): 1023-1033. http://dx.doi.org/10.1016/j.marpolbul.2006.01.007

Podvezko, V. 2012. Dominuojančiųjų alternatyvų daugiakriteriniai metodai, Lietuvos matematikos rinkinys: Lietuvos matematiku draugijos darbai. Serija B 53: 96-101. (in Lithuanian).

Podvezko, V.; Podviezko, A. 2010. Dependence of multi-criteria evaluation result on choice of preference functions and their parameters, Technological and Economic Development of Economy 16(1): 143-158. http://dx.doi.org/10.3846/tede.2010.09

Raikow, D. F.; Reid, D. F.; Blatchley, E. R.; Jacobs, G.; Landrum, P. F. 2007. Effects of proposed physical ballast tank treatments on aquatic invertebrate resting eggs, Environmental Toxicology and Chemistry 26(4): 717-725. http://dx.doi.org/10.1897/06-403R.1

Radziszewska-Zielina, E. 2010. Methods for selecting the best partner construction enterprise in terms of partnering relations, Journal of Civil Engineering and Management 16(4): 510-520. http://dx.doi.org/10.3846/jcem.2010.57

Rimkuvienè, D. 2002. Žemès ūkio verslo projektu efektyvumo vertinimo modelis: daktaro disertacija. Lietuvos žemès ūkio universitetas. 164 p. (in Lithuanian).

Rostamzadeh, R.; Ismail, K.; Zavadskas, E. K. 2014. Multi criteria decision making for assisting business angels in investments, Technological and Economic Development of Economy 20(4): 696-720. http://dx.doi.org/10.3846/20294913.2014.984364

Sutherland, T. F.; Levings, C. D.; Elliott, C. C.; Hesse, W. W. 2001. Effect of a ballast water treatment system on survivorship of natural populations of marine plankton, Marine Ecology Progress Series 210: 139-148. http://dx.doi.org/10.3354/meps210139

Šateikienè, D.; Janutènienè, J. 2012. Ballast water treatment technologies comparative analysis, in Transport means 2012: Proceedings of the 16th International Conference, 2526 October 2012, Kaunas, Lithuania, 241-244.

Šiožinyte, E.; Antuchevičienè, J.; Kutut, V. 2014. Upgrading the old vernacular building to contemporary norms: 
multiple criteria approach, Journal of Civil Engineering and Management 20(2): 291-298.

http://dx.doi.org/10.3846/13923730.2014.904814

Tang, Z.; Butkus, M. A.; Xie, Y. F. 2009. Enhanced performance of crumb rubber filtration for ballast water treatment, Chemosphere 74(10): 1396-1399.

http://dx.doi.org/10.1016/j.chemosphere.2008.11.048

Tang, Z.; Butkus, M. A.; Xie Y. F. 2006. Crumb rubber filtration: a potential technology for ballast water treatment, Marine Environmental Research 61(4): 410-423.

http://dx.doi.org/10.1016/j.marenvres.2005.06.003

Wu, D.; You, H.; Du, J.; Chen, C.; Jin, D. 2011a. Effects of UV/ Ag- $\mathrm{TiO}_{2} / \mathrm{O}_{3}$ advanced oxidation on unicellular green alga Dunaliella salina: implications for removal of invasive species from ballast water, Journal of Environmental Sciences 23(3): 513-519.

http://dx.doi.org/10.1016/S1001-0742(10)60443-3

Wu, D.; You, H.; Zhang, R.; Chen, C.; Lee, D.-J. 2011b. Ballast waters treatment using $\mathrm{UV} / \mathrm{Ag}-\mathrm{TiO}_{2}+\mathrm{O}_{3}$ advanced oxidation process with Escherichia coli and Vibrio alginolyticus as indicator microorganisms, Chemical Engineering Journal 174(2-3): 714- 718 .

http://dx.doi.org/10.1016/j.cej.2011.09.087

Zavadskas, E. K.; Turskis, Z.; Volvačiovas, R.; Kildienè, S. 2013. Multi-criteria assessment model of technologies, Studies in Informatics and Control 22(4): 249-258.

Zhang, N.; Ma, B.; Li, J; Zhang, Z. 2013. Factors affecting formation of chemical by-products during ballast water treatment based on an advanced oxidation process, Chemical Engineering Journal 231: 427-433.

http://dx.doi.org/10.1016/j.cej.2013.07.055 